\title{
INFLUENCE OF ADDING FUNCTIONALIZED MICROPARTICLES ON THE PHYSICAL- MECHANICAL, STRUCTURAL, AND PROCESSABILITY PROPERTIES OF THERMOPLASTIC RUBBER
}

\author{
Maria SÖNMEZ ${ }^{1 *}$, Laurenția ALEXANDRESCU ${ }^{1}$, Mihai GEORGESCU ${ }^{1}$, Dana GURĂU ${ }^{1}$, Ciprian CHELARU $^{1}$, Mircea \\ JUGĂNARU ${ }^{2}$, Anton FICAl ${ }^{3}$, Roxana TRUȘCĂ ${ }^{3}$
}

${ }^{1}$ INCDTP - Division: Leather and Footwear Research Institute, 93 Ion Minulescu, 031215 Bucharest, Romania, maria. sonmez@icpi.ro

${ }^{2}$ PROTECT STYL INDUSTRY S.R.L., 30 Bulevardul Unirii, 600192, Bacau, Romania

${ }^{3}$ POLITEHNICA University of Bucharest, Faculty of Applied Chemistry and Material Science, 1-7 Polizu St., Bucharest, Romania

Received: 03.12.2018

Accepted: 04.02.2019

https://doi.org/10.24264/Ifj.19.1.4

INFLUENCE OF ADDING FUNCTIONALIZED MICROPARTICLES ON THE PHYSICAL-MECHANICAL, STRUCTURAL, AND PROCESSABILITY PROPERTIES OF THERMOPLASTIC RUBBER

ABSTRACT. The aim of this paper was to assess the influence of powders, modified on the surface with organic-inorganic compounds, on the block copolymer styrene-butadiene-styrene (SBS) type thermoplastic rubber properties, obtained by the mixing. Powder surface of kaolin, $\mathrm{CaCO}_{3}$, and $\mathrm{MgCO}_{3}$ modification with precursors of $\mathrm{TiO}_{2}$ and $\mathrm{SiO}_{2}$ aimed at improving the interface, dispersion, and physico-mechanical properties, of the composites based on SBS. Titanium isopropoxide was used as a precursor to $\mathrm{TiO}_{2}$, and for $\mathrm{SiO}_{2}$ the tetraethyl orthosilicate (TEOS). Modified powders were morpho-structural characterized by SEM, FTIR, and EDAX. FTIR spectra highlight the bands characteristic of individual powders, but functional groups derived from $\mathrm{TiO}_{2}$ and $\mathrm{SiO}_{2}$ could not be viewed. Due to this issue, it has resorted to an EDAX analysis of all the powders, and the presence of silicon and/or titan elements confirmed that modification occurred. SEM microscopy performed on modified versus the simple powder, shows a reduction of areas containing particle agglomerations, due to the reduction of surface energy and implicitly electrostatic, and attraction forces. The results of the physical-mechanical properties, show that for the composites containing mixture of modified particles (even at high amounts 75\%) values of resistance to tear strength, elongation at break, elasticity, were superior to blends containing unmodified particles, to SBS respectively. The results obtained confirm that by modifying the particle surface, improves dispersion, and compatibility between phases, due to achieving optimal interface between particle/polymeric matrix. Melt flow index are lower for the reinforced SBS with high amounts of particles, but without raising issues of processability.

KEY WORDS: styrene-butadiene-styrene, carbonates, aluminum silicate, organic-inorganic compounds, characterization

\section{INFLUENṬA ADĂUGĂRII DE MICROPARTICULE FUNCȚIONALIZATE ASUPRA PROPRIETĂṬILOR FIZICO-MECANICE, STRUCTURALE ȘI DE} PRELUCRARE ALE CAUCIUCULUI TERMOPLASTIC

REZUMAT. Scopul acestei lucrări a fost evaluarea influenței pulberilor modificate la suprafață cu compuși organo-anorganici asupra proprietăților cauciucului termoplastic de tip bloc copolimer - stiren-butadienă-stiren (SBS), obținute prin procedeul de amestecare. Modificarea suprafeței pulberilor de caolină, $\mathrm{CaCO}_{3}$ și $\mathrm{MgCO}_{3} \mathrm{cu}$ precursori de $\mathrm{TiO}_{2}$ și/sau $\mathrm{SiO}_{2}$ a avut ca scop îmbunătățirea interfeței, dispersabilității și a proprietăților fizico-mecanice, ale compozitelor pe bază de SBS. Ca precursor de TiO, s-a utilizat izopropoxidul de titan iar pentru $\mathrm{SiO}_{2}$ - tetraetilortosilicatul (TEOS). Pulberile modificate au fost caracterizate morfo-structural prin SEM, FTIR și EDAX. Spectrele FTIR

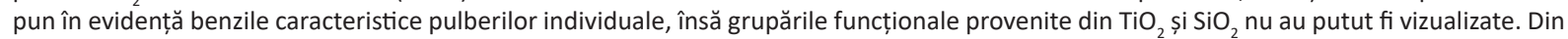
această cauză, s-a recurs la analiza pulberilor prin EDAX, care a confirmat faptul că modificarea a avut loc datorită prezenței elementelor siliciu și/sau titan, în cazul tuturor celor 3 tipuri de pulberi. Microscopia SEM efectuată pe pulberile modificate raportat la cele nemodificate arată o reducere a zonelor ce conțin aglomerări de particule, datorită reducerii energiei de suprafață și implicit a forțelor electrostatice, de atracție. Rezultatele fizico-mecanice arată ca în cazul compozitelor ce conțin amestec de particule modificate (chiar la cantități ridicate 75\%) se obțin valori ale rezistenței la rupere, tracțiune, sfâșiere, elasticitate, modul net superioare față de amestecurile ce conțin particule nemodificate, respectiv față de SBS. Rezultatele obținute confirmă faptul că, prin modificarea suprafeței particulelor, se îmbunătățește dispersabilitatea și compatibilitatea dintre faze datorită obținerii unei interfețe optime între particule/matrice polimerică. Indicii de fluiditate se reduc în cazul ranforsarii SBS-ului cu cantități ridicate de particule, fără însă a ridica probleme de procesabilitate.

CUVINTE CHEIE: stiren-butadienă-stiren, carbonați, alumino-silicat, compuși organo-anorganici, caracterizare.

\section{L'INFLUENCE DE L'ADDITIVATION DE MICROPARTICULES FONCTIONNALISÉES SUR LES PROPRIÉTÉS PHYSICO-MÉCANIQUES,} STRUCTURELLES ET DE TRAITEMENT DES CAOUTCHOUCS THERMOPLASTIQUES

RÉSUMÉ. Le but de cet article a été d'évaluer l'influence des poudres modifiées en surface avec des composés organo-inorganiques sur les propriétés du caoutchouc thermoplastique copolymère bloc styrène-butadiène-styrène (SBS) obtenu par le procédé de mélange. La modification de la surface des poudres de kaolin, $\mathrm{CaCO}_{3}$ et $\mathrm{MgCO}_{3}$ avec des précurseurs de $\mathrm{TiO}_{2}$ et/ou SiO 2 visait à améliorer l'interface, la dispersibilité et les propriétés physico-mécaniques des composés à base de SBS. L'isopropoxyde de titane a été utilisé comme précurseur du $\mathrm{TiO}_{2}$ et le tétraéthylortosilicate (TEOS) comme précurseur du $\mathrm{SiO}_{2}$. Les poudres modifiées ont été caractérisées du point de vue morphostructurel par MEB, FTIR et EDAX. Les spectres FTIR mettent en évidence les bandes caractéristiques des poudres individuelles, mais les groupes fonctionnels dérivés de $\mathrm{TiO}_{2}$ et de $\mathrm{SiO}_{2}$ n'ont pas pu être visualisés. Pour cette raison, une analyse EDAX a été réalisée sur les poudres, ce qui a confirmé que la modification était due à la présence d'éléments en silicium et/ou en titane dans les trois types de poudres. La microscopie au MEB réalisée sur les poudres modifiées par rapport aux poudres non modifiées montre une réduction des zones contenant des agglomérats de particules due à la réduction de l'énergie de surface et, implicitement, des forces d'attraction électrostatiques. Les résultats physico-mécaniques montrent que, dans le cas de composés contenant un mélange de particules modifiées (même à des volumes élevés, $75 \%)$, les valeurs de résistance à la déchirure, à la traction, l'élasticité et le module sont nettement supérieures aux mélanges contenant des particules non modifiées, c'est-à-dire à SBS. Les résultats obtenus confirment que, en modifiant la surface des particules, la dispersibilité et * Correspondence to: Maria SÖNMEZ, INCDTP - Division: Leather and Footwear Research Institute, 93 Ion Minulescu, 031215 Bucharest, Romania, maria.sonmez@icpi.ro 
la compatibilité entre les phases sont améliorées en obtenant une interface optimale entre les particules/matrice de polymère. Les rapports de fluidité sont réduits lorsque le SBS est renforcé avec de grandes quantités de particules, mais ne posent pas de problèmes de capacité de traitement.

MOTS CLÉS : styrène-butadiène-styrène, carbonates, aluminosilicate, composés organo-inorganiques, caractérisation

\section{INTRODUCTION}

Filling materials are one of the most important additives used in the rubber processing industry $[1,2]$. Using filling materials can improve processability and bring numerous economic benefits. However, the efficiency of reinforcement depends on the properties of the filler, the particle size, shape, surface area, degree of dispersion as well as the interactions taking place with the polymer $[3,4]$. The properties of the composite materials could be optimized by increasing the size of the interface and modifying the strength of bonds/interactions that occur between the polymer matrix and the filler. An increase of interface dimensions could be achieved by reducing particle size to nanometer. This decrease to nanometric level in particle size leads to a higher degree of agglomeration, to a poor dispersion and reduced physico-mechanical, chemical and thermal properties [5]. These properties could be obtained by modifying the surface of the particles with different coupling agents. Adding a surface-modified nano (micro) filler can improve properties because it reduces surface hydrophilia, improves dispersion and interactions that occur at the interface. Styrenebutadiene-styrene thermoplastic rubber is one of the most widely used elastomers in various industrial applications, mainly due to its high filling capacity, high flexural strength, etc. Therefore, in the case of the development of composite materials, SBS plays the role of polymer matrix [6].

The most common reinforcing agents used in polymers are organic and inorganic. Among the most commonly used inorganic particles are $\mathrm{SiO}_{2}, \mathrm{TiO}_{2}, \mathrm{CaCO}_{3}$, talc, polyhedral oligomeric silsesquioxane (POSS), carbon fiber, montmorillonite clay (MMT), multi-wall carbon nanotubes [7-10], carbon black [11], nanodiamond [12], boron carbide [13] etc. Of these, calcium carbonate $\left(\mathrm{CaCO}_{3}\right)$ is the most commonly used as a filler material in various polymers. However, due to the hydrophilic nature of the surface, $\mathrm{CaCO}_{3}$ is incompatible with the vast majority of polymers - hydrophobic. Moreover, calcium carbonate has a very low surface chemical activity. Due to this issue, it is used rather as a conventional filler material (for cost reduction) and not as an active reinforcement agent, capable of improving some properties of interest (physico-mechanical, chemical, thermal, etc.). In order to be used as an active reinforcement agent, it is necessary to modify its surface with coupling agents or with organic acids [14]. The most common organic acid used to modify the surface of $\mathrm{CaCO}_{3}$ is stearic acid. Its presence on the $\mathrm{CaCO}_{3}$ surface induces surface hydrophobicity and implicitly improves compatibility with various polymers such as high density polyethylene (HDPE), polypropylene (PP), etc. [15]. Surface treatment leads to the reduction of particle-particle interactions and the increase of matrix/filler adhesion. However, $\mathrm{SiO}_{2}$ particle surface modification is much easier than $\mathrm{CaCO}_{3}$, because it has more reactive surface groups. Calcium carbonate does not contain $-\mathrm{OH}$ groups on its surface and therefore the percentage of silane left over by the modification is reduced by about $19 \%$. In the case of mineral clays, due to the presence of $\mathrm{Si}-\mathrm{OH}$ and $\mathrm{Al}-\mathrm{OH}$ on the surface, it is possible to form covalent bonds with silanol. The percentage of silane remaining on the clay surface is about $66 \%$ [16]. A recently reported method for modifying the surface of precipitated $\mathrm{CaCO}_{3}$ (PCC) was to modify the surface with silica produced by solgel method. The PCC surface was modified with silica produced via hydrolysis and condensation reactions of tetraethylorthosilicate (silica precursor) in ethanol/water solutions under alkaline conditions [17]. Another method for modifying $\mathrm{CaCO}_{3}$ was to treat the surface with a mixture of silane coupling agents, amino- and mercapto groups for use as reinforcing agent in 
isoprene rubber. The amount of chemisorbed silanes on the surface of $\mathrm{CaCO}_{3}$ measured by thermogravimetry indicates a higher amount of aminosilane than mercaptosilane, and higher for the trialkoxy structure than for dialkoxy. Moreover, higher values for stress at $500 \%$ strain, fracture stress, and elongation at break were determined for the treatment with amino- and mercapto-functional silanes having a trialkoxy structure from the stress-strain curves of composite. Treating the mixture with silanes containing mercapto and amino functional groups having the dialkoxy structure did not sufficiently improve the mechanical properties [18]. Another method presented in the literature for the chemical modifying the surface of calcium carbonate particles was focused on the grafting reaction using maleic anhydride grafting polyethylene wax (MA-g-PEW) as a coupling agents, having a weight ratio between MA-g-PEW and $\mathrm{CaCO}_{3}$ ranging between 1 to 2.5 wt\%. FTIR spectra showed that by this method, surface modification of $\mathrm{CaCO}_{3}$ was achieved by chemical bonding [19]. Other methods for improving the compatibility of calcium nanosize carbonate with PVC matrix have been focused on surface modification using polymerization in the presence of 2 monomers, methyl methacrylate (MMA) and Butyl acrylate (BA) [20]. Kaolin is a natural, nontoxic and inexpensive layered alumino silicate with a chemical structure rich in reactive hydroxyl groups, capable of numerous chemical and ion exchange reactions. Kaolinite is the most commonly 1:1 (two-sheet) - type clay mineral with its basic unit consisting of a tetrahedral sheet of $\mathrm{SiO}_{2}$ siloxane units and an octahedral sheet of $\mathrm{AlO}_{2}(\mathrm{OH})_{4}$. After modification, kaolinite particles can become evenly dispersed in the rubber matrix and be used as a functional filler for rubber because of its light color, special stratified structure, and availability [19].

Therefore, kaolin is considered an excellent substrate for anchoring metal oxides, with applications in many fields. Different $\mathrm{TiO}_{2}$ precursors $\left(\mathrm{TiCl}_{4}, \mathrm{TiOSO}_{4}\right.$ and $\mathrm{Ti}$ (IV) alkoxides respectively) were used to modify kaolin [21]. Other coupling agents (octadecylamine, N(3-trimethoxysilyl) propyl ethylene diamine and bis- ( $\gamma$-triethoxysilylpropyl) -tetrasulfide-
Si69) were used to modify the surface of the layered clays in order to improve compatibility with styrene butadiene rubber [22, 23]. Due to the fact that the layered clays have reactive free $-\mathrm{OH}$ groups, modification with coupling agents is much easier compared to carbonates. However, an absolutely necessary condition is that these coupling agents are able to react with these hydroxyl groups. By using coupling agents, the hydrophilic surface of the particles is transformed into hydrophobic, thereby improving compatibility and dispersion in the polymeric matrix. However, the effect of modifying the surface with these coupling agents depends largely on the number of hydroxyl groups present on the surface of the fillers. Unfortunately, the vast majority of inorganic particles possess a low number of hydroxyl groups on the surface. Therefore, it is important to increase the number of hydroxyl groups on the surface of some inorganic agents [24]. Of the magnesium compounds, the most commonly used as reinforcing agents in the various polymers are simple magnesium hydrates or modified with fatty acids, titanate coupling agents, silane coupling agents, etc $[25,26]$.

The purpose of this paper was to evaluate the influence of kaolin, $\mathrm{CaCO}_{3}$, and $\mathrm{MgCO}_{3}$ particles unmodified/modified with organoinorganic compounds $\left(\mathrm{TiO}_{2}\right.$ and/or $\left.\mathrm{SiO}_{2}\right)$ on the physico-mechanical, structural and processability properties of the styrene-butadiene-styrene block copolymer rubber (SBS).

\section{EXPERIMENTAL}

\section{Materials}

The following raw materials were used in the experiments: Calcium carbonate (type OmyaCarb10-AZ), from Omya North America with the following specifications: specific gravity -2.70 $\mathrm{g} / \mathrm{cc}$, brightness $-94 \%$, moisture absorption at equilibrium $-0.070 \%$, particle size $-12 \mu \mathrm{m}$, calcium carbonate $\%-97$, magnesium carbonate $\%-0.5$, retained in 325 mesh (dry) ppm - 0.2; Magnesium Carbonate - grade standard: food grade, industrial grade, color: white, boiling point: $540^{\circ} \mathrm{C}$, melting point: $700^{\circ} \mathrm{C}\left(1292^{\circ} \mathrm{F}\right)$, molecular 
Maria SÖNMEZ, Laurenţia ALEXANDRESCU, Mihai GEORGESCU, Dana GURĂU, Ciprian CHELARU, Mircea JUGĂNARU, Anton FICAI,

\section{Roxana TRUŞCĂ}

weight: $485 \mathrm{~g} / \mathrm{mol}$; solubility: insoluble in cold water, hot water, alcohol, purchased from Bridgexim SRL; Kaolin - calcined (Snowpaque), purchased from Bridgexim SRL; Tetraethyl orthosilicate (TEOS) reagent grade, assay - 98\%, molecular weight 208.33; Dimethylpolysiloxane - viscosity 500cSt $\left(25^{\circ} \mathrm{C}\right)$ (lit.); Titanium (IV) isopropoxide, $\geq 97 \%$, molecular weight: 284.22 , density: $0.96 \mathrm{~g} / \mathrm{mL}$ at $20^{\circ} \mathrm{C}$ (lit.) from Sigma Aldrich, Ethyl Alcohol - for analysis, molecular weight: 46.07 acquired from Chimreactiv SRL, Styrene-butadiene-styrene rubber (SBS) - type Eurruber from Tecnofil SME, Italy.

\section{Methods}

\section{Modifying Kaolin, Calcium, and Magnesium Carbonate Particles with Organo-Inorganic Compounds}

In the first stage, 100 grams of kaolin powder was immersed/coated with ethyl alcohol (reaction medium) and mixed with a magnetic stirrer until full dispersion of the powders, at 300 $\mathrm{rpm}$ and temperature of $40-50^{\circ} \mathrm{C}$. Next stage, $10 \mathrm{~mL}$ of titanium isopropoxide was added as fine drops and kept under continuous stirring for another $2 \mathrm{~h}$. To achieve the hydrolysis of the organo-titanates in the powder mass, $10 \mathrm{~mL}$ of distilled water was added, and stirred for another 20 minutes. The resulting mixture is then vacuum filtered and washed with abundant alcohol to remove the excess functional agent, dried at $80^{\circ} \mathrm{C}$, and milled. Calcium, and magnesium carbonate were modified in similar conditions to kaolin, with the mention that, due to the lack of the $-\mathrm{OH}$ reactive groups on their surface, the silicon precursor - TEOS to obtain silanolic bonds was introduced in the first stage, followed by the addition of droplets of titanium isopropoxide. Moreover, the amount of precursors added was calculated so that $5 \mathrm{~g}$ of $\mathrm{SiO}_{2}(18.6 \mathrm{~mL})$, and $5 \mathrm{~g}$ of $\mathrm{TiO}_{2}(24.67 \mathrm{~mL})$ were finally obtained, the rest of the stages being the same as in the case of kaolin modification.

\section{Obtaining Composites based on SBS / Unfunctionalized or Functionalized Particles}

Composites based on SBS reinforced with varying percentages of modified/unmodified (15, 45 and $75 \%$ ) mixed particles were processed on a Brabender mixer with capacity of $370 \mathrm{~cm}^{3}$. Prior to blending, both unmodified/modified powders and SBS rubber were subjected to a pre-drying process, in a hot air oven at $103^{\circ} \mathrm{C}$ for a minimum of 2 hours. After drying, the formulations presented in Table 1 were processed in the Brabender mixer at $160^{\circ} \mathrm{C}$ and a speed between $30 \mathrm{rpm}$ for 1 minute, and $130 \mathrm{rpm}$ for 3 minutes. The total processing time in the Brabender mixer was 4 minutes, for every composites processed.

Table 1: Formulations based on SBS rubber reinforced with unmodified/modified particles, wt\%

\begin{tabular}{lccccccc}
\hline \multicolumn{1}{c}{ Sample / Raw materials } & $\mathrm{SBS}$ & 1 & 2 & 3 & 4 & 5 & 6 \\
\hline SBS rubber & 100 & 100 & 100 & 100 & 100 & 100 & 100 \\
Kaolin & & 5 & & 15 & & 25 & \\
$\mathrm{CaCO}_{3}$ & & 5 & & 15 & & 25 & \\
$\mathrm{MgCO}_{3}$ & & 5 & & 15 & & 25 & \\
$\mathrm{Kaolin} / 10 \% \mathrm{TiO}_{2}$ & & & 5 & & 15 & & 25 \\
$\mathrm{CaCO}_{3} / 5 \% \mathrm{SiO}_{2}+5 \% \mathrm{TiO}_{2}$ & & & 5 & & 15 & & 25 \\
$\mathrm{MgCO}_{3} / 5 \% \mathrm{SiO}_{2}+5 \% \mathrm{TiO}_{2}$ & & & 5 & & 15 & & 25 \\
\hline
\end{tabular}

From the blends processed on Brabender 150x150x4 mm sheets were obtained, by pressing in the mold at the following optimal parameters: plate temperature $-170^{\circ} \mathrm{C}$; preheating -2 minutes, pressing -2 minutes, cooling -8 minutes, and pressure $-300 \mathrm{kN}$.

From the composites sheets obtained, dumbbell specimen for tensile strength, and panting specimen - tear resistant were cut out. After conditioning for 24 hours at room temperature, are subjected to physicomechanical and structural determinations (FTIR).

\section{RESULTS AND DISCUSSIONS}

\section{FT-IR Analysis of Particles and Composite Blends}

The FTIR spectra recorded on the powders of kaolin, $\mathrm{MgCO}_{3}$ and $\mathrm{CaCO}_{3}$ simple and modified with organo-inorganic groups are shown in Figures 1-3.

In the case of the FTIR spectrum recorded on simple kaolin, the following characteristic bands could be identified. The $3681 \mathrm{~cm}^{-1}$ band 
is attributed to the stretching $-\mathrm{OH}$ interlamellar groups of the Al-O-H bond, and that of 3619 $\mathrm{cm}^{-1}$ is associated with stretching bond of intralamellar -OH groups [27]. The group at $3619 \mathrm{~cm}^{-1}$ is characteristic of the high amounts of $\mathrm{Al}-\mathrm{OH}$ in the octahedral layer. The bands at 3407 and 1648 $\mathrm{cm}^{-1}$ are characteristic stretch and deformation bonds of the $-\mathrm{OH}$ group in the adsorbed physical water. The band at $1112 \mathrm{~cm}^{-1}$ is characteristic of the Si-O stretch bond, and the 788 and 750 $\mathrm{cm}^{-1}$ is attributed to the bending vibration of Si-O-Al bonding in the inner layer. The band at 989 and $638 \mathrm{~cm}^{-1}$ is attributed to bending bond of $-\mathrm{OH}$ and $\mathrm{Si}-\mathrm{O}$ groups, respectively [28]. The $680 \mathrm{~cm}^{-1}$ band is characteristic of the $\mathrm{Mg} /$ $\mathrm{Al}-\mathrm{OH}$ bond and the $514 \mathrm{~cm}^{-1}$ characteristic to stretching bond of $\mathrm{Fe}-\mathrm{O}, \mathrm{Fe}_{2} \mathrm{O}_{3}$ or Si-O-Al, similar to the results obtained by other researchers [29, 30]. In the case of kaolin powders modified with $10 \%$ titanium isopropoxide, the characteristic band of the $\mathrm{OH}$-interlamellar from $\mathrm{Al}-\mathrm{OH}$ bond at 3681 (simple kaolin) shifts to $3685 \mathrm{~cm}^{-1}$, and the disappearance of the $-\mathrm{OH}$ bands at 3407 and $1648 \mathrm{~cm}^{-1}$, as a result of the functionalization reactions involving $\mathrm{OH}$ groups in kaolin and which also reduce its affinity to bind/adsorb the moisture, is observed. Weak vibrations of stretch-C-H bonds can also be seen close to 2900 $\mathrm{cm}^{-1}$. The significant shift of the bands from 989 to $997 \mathrm{~cm}^{-1}$ and 514 to $522 \mathrm{~cm}^{-1}$, respectively, can be observed in the case of titanium isopropoxide modified kaolin, sufficiently large displacements that demonstrate the functionalization of kaolin.
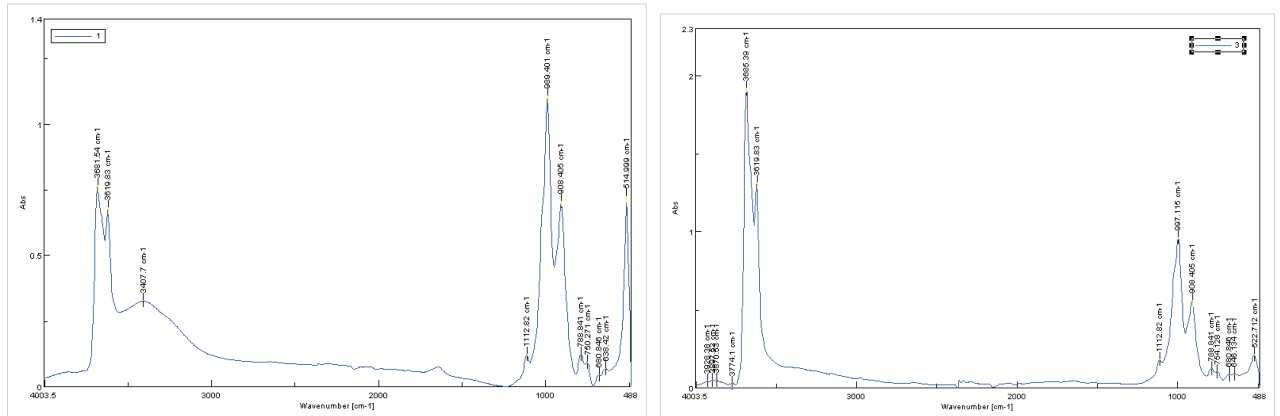

Figure 1. The FTIR spectra of unmodified (left) kaolin and kaolin modified with $10 \%$ titanium isopropoxide (right)

In the FTIR spectra recorded on the simple $\mathrm{CaCO}_{3}$ powder (Figure 2, left), it can be seen $\left(3597 \mathrm{~cm}^{-1}\right)$ having a low intensity the $-\mathrm{OH}$ bond of $\mathrm{Ca}(\mathrm{OH})_{2}$ left behind after the carbonation process. The bands of 1388 (stretching mode), 871 (O-C-O bending-out plane deformation) and 709 (O-C-O bending-in-plane deformation) $\mathrm{cm}^{-1}$ correspond to the three different C-O stretching modes, and the one of 2514 (are

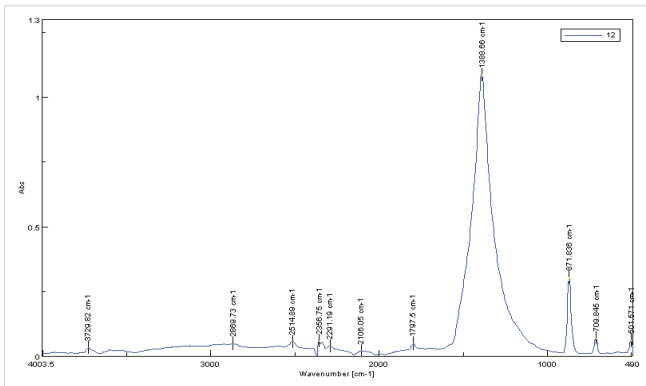

Figure 2. FTIR spectra of the simple $\mathrm{CaCO}_{3}$ powder (left) and $\mathrm{CaCO}_{3} / 5 \% \mathrm{TEOS}+5 \%$ titanium isopropoxide (right)

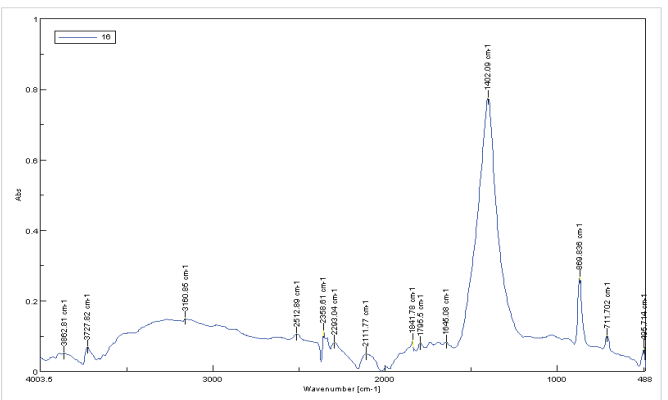

harmonic vibration of these elongation modes). The low intensity bands at 2869 and $1797 \mathrm{~cm}^{-1}$ correspond to $\mathrm{C}=\mathrm{O}$ bonds in the carbonate ion. The $501 \mathrm{~cm}^{-1}$ band is associated with Ca-O bonds [31, 32]. In the case of $\mathrm{CaCO}_{3} / 5 \%$ TEOS $+5 \%$ titanium isopropoxide powder (Figure 2), the characteristic bands are shifted, especially from 1388 to $1402 \mathrm{~cm}^{-1}$, which proves that the carbonate is altered throughout the mass. 
Maria SÖNMEZ, Laurenţia ALEXANDRESCU, Mihai GEORGESCU, Dana GURĂU, Ciprian CHELARU, Mircea JUGĂNARU, Anton FICAI, Roxana TRUŞCĂ

Figure 3 (A) shows the FTIR spectrum of styrene-butadiene-styrene thermoplastic rubber. The bands 3066 and $3020 \mathrm{~cm}^{-1}$ are associated with the stretching vibrations of the $\mathrm{CH}_{2}$ bond of the polybutadiene, and the $\mathrm{CH}$ groups in the aromatic ring (styrene). The band $2920 \mathrm{~cm}^{-1}$ and $2850 \mathrm{~cm}^{-1}$ are associated with the asymmetric and symmetrical stretch vibration of the $\mathrm{CH}_{2}$ bond in the polybutadiene unit. The band at $1601 \mathrm{~cm}^{-1}$ is attributed to the stretch vibration of the carbon atoms in the aromatic ring. The band at $1450 \mathrm{~cm}^{-1}$ can be associated with the bending vibrations of the $\mathrm{CH}_{2}$ group of the cis- and transpolybutadiene units, or the stretch bond of the $\mathrm{C}-\mathrm{O}$ group. In this case, it seems, to be associated with the filling used in SBS, namely, calcium carbonate. The $1072 \mathrm{~cm}^{-1}$ band is characteristic of polystyrene units, and those of $1026 \mathrm{~cm}^{-1} \mathrm{can}$ be attributed both to polystyrene groups and vibrations of $\mathrm{C}-\mathrm{C}$ bond from cis-polybutadiene.
The bands of 964 and $906 \mathrm{~cm}^{-1}$ can be associated with out-of-plane (wagging) vibrations of $\mathrm{CH}$ groups near the double bond in trans- and vinyl- polybutadiene units. The band at $752 \mathrm{~cm}^{-1}$ and $694 \mathrm{~cm}^{-1}$ represents the bending vibration and out-of-plane bending of the $\mathrm{CH}$ bond in the aromatic ring. The band at $540 \mathrm{~cm}^{-1}$ is also characteristic of polystyrene units $[33,34]$. In the case of the spectrum recorded on the composite - SBS / 75\% mixture of (Kaolin - 10\% titanium isopropoxide, $\mathrm{CaCO}_{3}-5 \%$ TEOS $+5 \%$ titanium isopropoxide; $\mathrm{MgCO}_{3}-5 \%$ TEOS + 5\% titanium isopropoxide) (Figure 3, B), the characteristic kaolin bands can be highlighted at 3694 and $3617 \mathrm{~cm}^{-1}$. The bands characteristic of $\mathrm{TiO}_{2}, \mathrm{SiO}_{2^{\prime}}$ magnesium or calcium carbonate could not be observed due to their content, and especially their molar absorptions compared to SBS, are moderate.
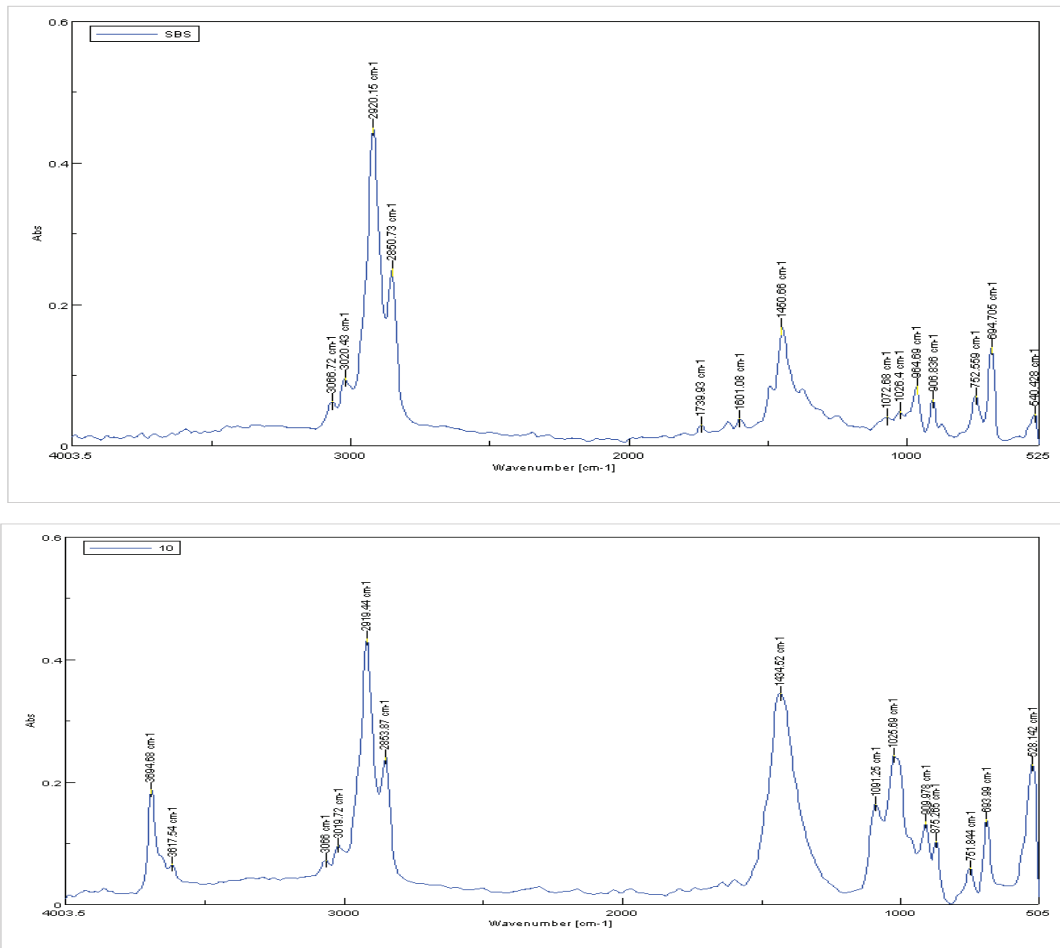

Fig. 3. The FTIR spectra of SBS and composite rubber - SBS / 75\% (Kaolin/ 10\% TiO2, CaCO3 / 5\% TEOS / 5\% Titanium Isopropoxide, and MgCO3 / 5\% TEOS / 5\% Titanium Isopropoxide (10)

\section{EDAX Analysis of Unmodified / Modified Particles}

The EDS analysis is a useful method of identifying constituents in the sample as well as their relative ratio. As can be seen from Figure 4 (left) obtained on simple kaolin, the following elements could be identified: $\mathrm{O}, \mathrm{C}, \mathrm{Si}, \mathrm{Al}, \mathrm{Fe}$ and
K. Based on these elements it can be concluded that the used kaolin is not of advanced purity, due to the identification of slight Fe and K. In the case of the spectrum recorded on kaolin powder modified with $10 \%$ titanium isopropoxide (Figure 4 , right) besides the elements identified in pure kaolin, the presence of $\mathrm{Ti}$ element at different 
intensities can be visualized, which demonstrates that functionalization took place. In the case of the spectrum recorded on the powder of simple $\mathrm{CaCO}_{3}$ (Figure 5, left) the following could be visualized, $\mathrm{C}, \mathrm{O}$ and $\mathrm{Ca}$, confirming the advanced purity of this type of powder. In the case of modified $\mathrm{CaCO}_{3}$ powders with silicon and titanium precursors (Figure 5, right), the Si and Ti elements could also be seen. In this case, it is confirmed that the chosen functionalization
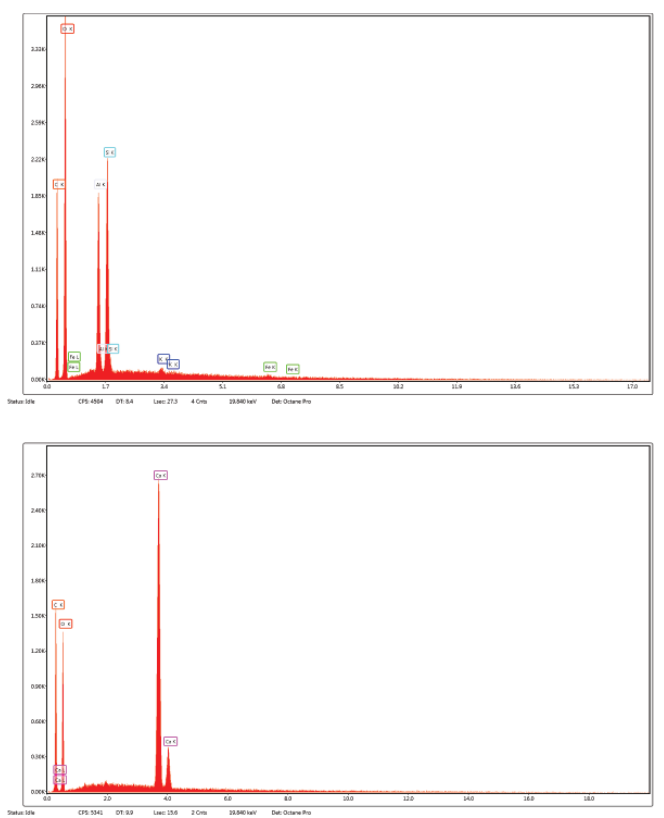

method allows the successful modification of these powders. Quantitative analysis of these powders Table 2, shows the weight and atomic ratio between components. As can be seen, in the case of $\mathrm{MgCO}_{3}$ powder, a higher percentage of titanium and silicon is retained on the surface compared to that obtained on the $\mathrm{CaCO}_{3}$ powder, indicating a higher affinity of these powders for the functionalization process.
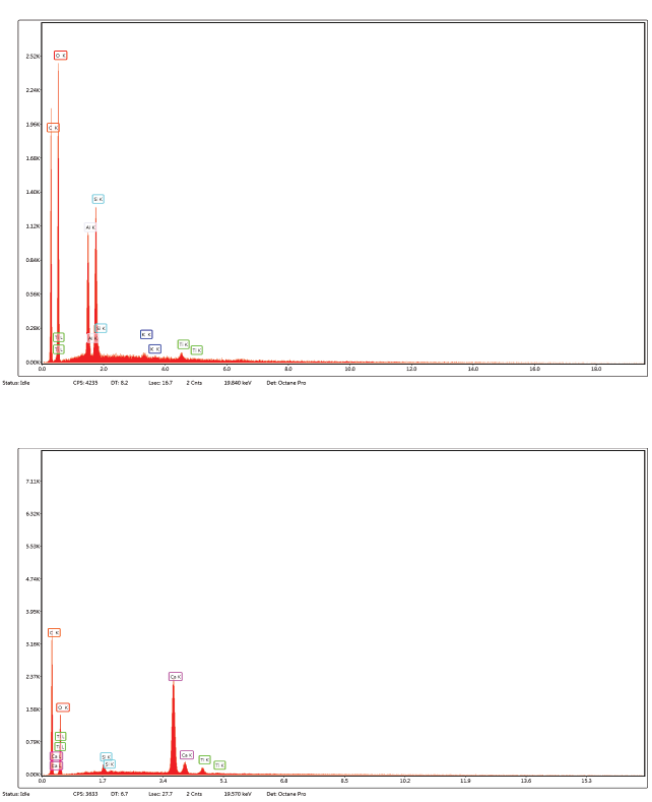

Figure 4. EDS analysis recorded on kaolin powder (left) and kaolin/10\% titanium isopropoxide (right) Figure 5. EDS spectra obtained on $\mathrm{CaCO}_{3}$ powder (left) and $\mathrm{CaCO}_{3} / 5 \% \mathrm{TEOS}+5 \%$ titanium isopropoxide (right)

Table 2: Quantitative analysis of kaolin, $\mathrm{CaCO}_{3}$, and $\mathrm{MgCO}_{3}$ unmodified/modified powders

\begin{tabular}{|c|c|c|}
\hline Element & Weight \% & Atomic \% \\
\hline \multicolumn{3}{|c|}{ Kaolin } \\
\hline $\mathrm{OK}$ & 67.44 & 78.32 \\
\hline Al K & 13.98 & 9.63 \\
\hline Si K & 17.6 & 11.64 \\
\hline K K & 0.62 & 0.3 \\
\hline Fe K & 0.35 & 0.12 \\
\hline \multicolumn{3}{|c|}{ Kaolin/10\% titanium isopropoxide } \\
\hline $\mathrm{OK}$ & 68.56 & 79.35 \\
\hline Al K & 13.66 & 9.38 \\
\hline Si K & 16.04 & 10.58 \\
\hline K K & 0.59 & 0.28 \\
\hline Ti K & 0.68 & 0.26 \\
\hline Fe $\mathrm{K}$ & 0.46 & 0.15 \\
\hline $\mathrm{OK}$ & 68.56 & 79.35 \\
\hline $\mathrm{Al} \mathrm{K}$ & 13.66 & 9.38 \\
\hline \multicolumn{3}{|c|}{$\mathrm{CaCO}$} \\
\hline $\mathrm{CK}$ & 33.01 & 43.45 \\
\hline $\mathrm{OK}$ & 50.76 & 50.15 \\
\hline $\mathrm{Ca} \mathrm{K}$ & 16.23 & 6.4 \\
\hline \multicolumn{3}{|c|}{$\mathrm{CaCO} / 5 \%$ TEOS $/ 5 \%$ titanium isopropoxide } \\
\hline $\mathrm{CK}^{2}$ & 50.02 & 60.22 \\
\hline $\mathrm{OK}$ & 40.01 & 36.16 \\
\hline Si K & 0.45 & 0.23 \\
\hline Ca K & 8.86 & 3.2 \\
\hline $\mathrm{Ti} \mathrm{K}$ & 0.66 & 0.2 \\
\hline
\end{tabular}


Maria SÖNMEZ, Laurenţia ALEXANDRESCU, Mihai GEORGESCU, Dana GURĂU, Ciprian CHELARU, Mircea JUGĂNARU, Anton FICAI, Roxana TRUŞCĂ

\begin{tabular}{ccc}
\hline \multicolumn{3}{c}{$\mathrm{MgCO}_{3}$} \\
\hline $\mathrm{C} \mathrm{K}$ & 18.13 & 25.18 \\
$\mathrm{O} \mathrm{K}$ & 48.88 & 50.97 \\
$\mathrm{Mg} \mathrm{K}$ & 32.99 & 23.84 \\
\hline $\mathrm{MgCO} / 5 \% \mathrm{TEOS} / 5 \%$ titanium & isopropoxide \\
\hline $\mathrm{C} \mathrm{K}$ & 40.82 & 50.88 \\
$\mathrm{O} \mathrm{K}$ & 39.78 & 37.22 \\
$\mathrm{Mg} \mathrm{K}$ & 16.71 & 10.88 \\
$\mathrm{Si} \mathrm{K}$ & 0.8 & 0.43 \\
$\mathrm{Ti} \mathrm{K}$ & 1.89 & 0.6 \\
\hline
\end{tabular}

\section{SEM Analysis of Unmodified / Modified Powders and Composite}

SEM microscopy performed on unfunctionalized kaolin powder (Figure 6, image A) shows a relatively spherical shape of these as well as the presence of some areas with particle agglomerations. Agglomeration of untreated particles is due to electrostatic forces of attraction. As a result of the functionalization of kaolin with titanium isopropoxide (Figure A"), particle agglomeration zones are substantially reduced due to the modification of the surface with oxidic compounds, which reduce the surface energy and, implicitly, the electrostatic forces of attraction [35]. Thus, clear contours are observed between the particles, and their size is between 170 and $250 \mathrm{~nm}$.
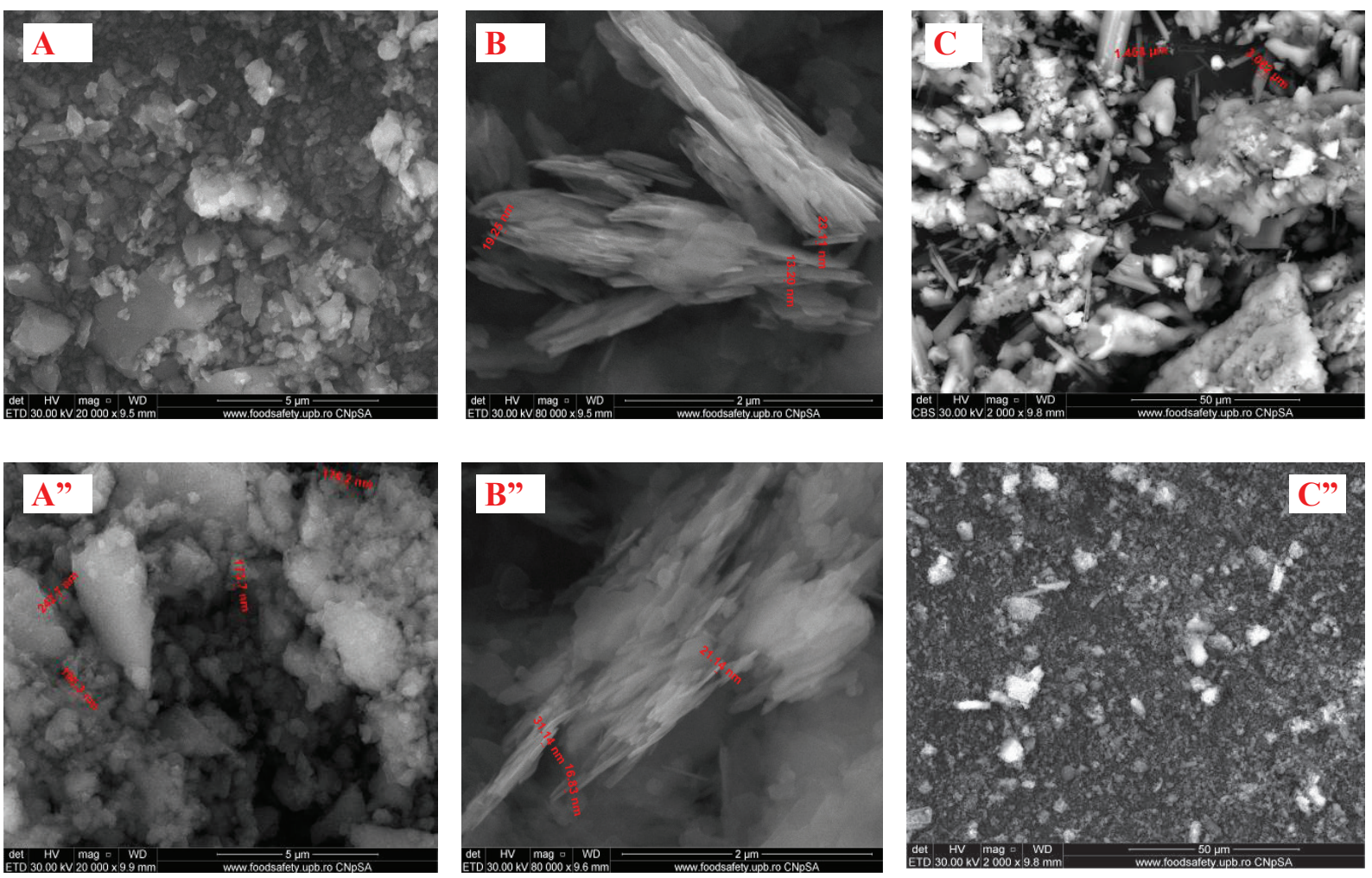

Figure 6. SEM images of unmodified and modified $\mathrm{CaCO}_{3}(\mathrm{~A})$, kaolin $(\mathrm{B})$ and $\mathrm{MgCO}_{3}(\mathrm{C})$ powders $\mathrm{CaCO}_{3}-5 \%$ TEOS-5\% titanium isopropoxide $\left(A^{\prime \prime}\right)$, kaolin modified with $10 \%$ titanium isopropoxide (B), and $\mathrm{MgCO}_{3}-5 \%$ TEOS-5\% titanium isopropoxide ( $\left.\mathrm{C}^{\prime \prime}\right)$

The SEM images of commercial kaolin powder (Figure 6, image B), show its layered structure, the layer size being between 13.2$23.1 \mathrm{~nm}$. Following the modification of kaolin with silicon and titanium precursors (image B"), a clear mapping / movement of the layers is observed due to Si and Ti localization between them. The size of the layers is not influenced by the presence of these inorganic powders, being maintained between 16.83-31.14 nm.

The SEM image obtained on commercial magnesium carbonate (Figure 6, image C), highlights an extremely varied morphology of the particles (filiform, spherical, cylindrical) with dimensions between 1.4-3 $\mu \mathrm{m}$ and an advanced agglomeration. Following the modification with 
TEOS and titanium isopropoxide (Figure 6, image $\left.C^{\prime \prime}\right)$, an advanced disaggregation is observed, due to the reduction of the electrostatic attraction forces.

The SEM images obtained on the SBS/ $75 \%$ unmodified particle mixture (Figure 7, left) show a reasonable distribution of SBS mass. However, in some areas, areas with slight particle agglomerations or gaps (probably due to particle detachment following fracture of the samples in liquid nitrogen) can be seen, prior starting the analysis. In contrast, for the composites containing the same amount of particulate mixture but modified (Figure 7, right image), an advanced reduction of the voids and particle agglomerates is observed, due to their very good dispersion and compatibility with the polymer mass.
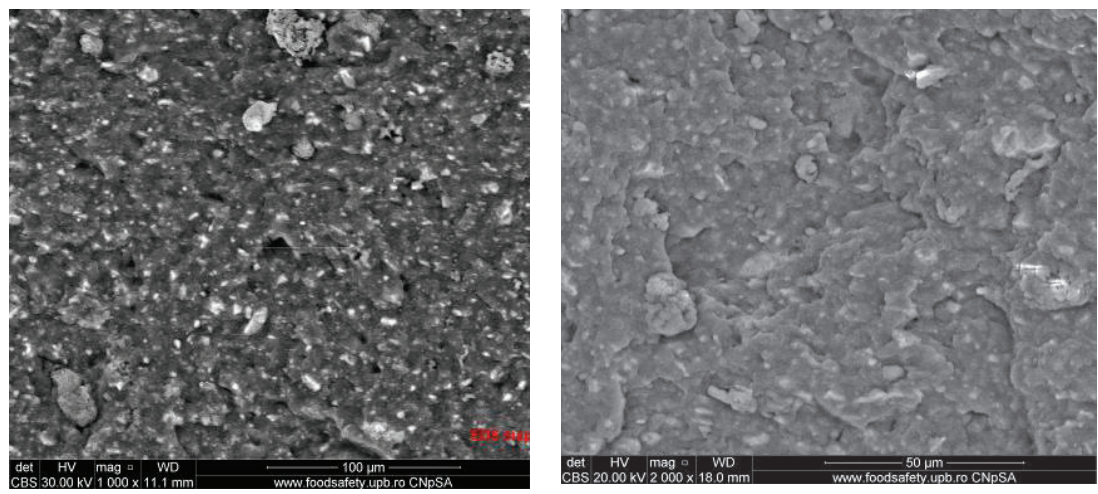

Figure 7. SEM image recorded on SBS composite - 75\% unmodified particles - kaolin, $\mathrm{CaCO}_{3}$ and $\mathrm{MgCO}_{3}$ (left), and SBS-75\% modified particles - kaolin, $\mathrm{CaCO}_{3}$ and $\mathrm{MgCO}_{3}$ (right)

\section{Physico-mechanical and Rheological Characterization of Composite Materials based on SBS}

The physico-mechanical results obtained on SBS-based polymeric composites reinforced with different ratios of modified/unmodified particulate mixture (kaolin, $\mathrm{CaCO}_{3}$ and $\mathrm{MgCO}_{3}$ ) are presented in In most cases, elasticity and elongation at break decrease with the increase in the amount of powders, due to reduced mobility of the macromolecular chains. Instead, higher values of the $100 \%$ modulus were obtained mainly for high hardness mixtures, respectively, when modified particles were used. The flow properties of composite mixtures improve if a mixture of unfunctionalized/functionalized particles is used up to a percentage of $(15 \%$ and $45 \%$ ), respectively, of the reference sample (SBS). In contrast, for composites containing high amounts of particles $75 \%$, the flow properties drop to $244-132 \mathrm{~g} / 10 \mathrm{~min}$. However, during the process of obtaining the composites, there were no problems of processability.

Table 3. As can be seen, for all the composites obtained, the physical and mechanical properties are significantly higher than those obtained on the unmodified rubber. For samples 1 and 2, containing 15\% of the three particle types, the hardness does not vary with the reference value. In contrast, in the case of mixtures containing high amounts of particulate mixture 45\% (Samples 3 and 4), and 75\% (Samples 5 and 6), the hardness gradually increases with the amount of particles. Moreover, in the case of mixtures containing powders modified with $\mathrm{TiO}_{2}$ and $\mathrm{SiO}_{2}$ (Samples 4 and 6), higher hardnesses are obtained, at the same degree of reinforcement compared to mixtures containing unmodified powders (Samples 3 and 5). Tensile strength is significantly improved over SBS for all blends. However, if modified particles (Samples 2, 4 and 6) are used, the tensile strength is higher compared to those containing unmodified particles (1, 3 and 5). This was to be expected, because by modifying the surface of the particles, the dispersion and adhesion with the SBS matrix improves. The highest value for the tear strength was obtained for the mixture containing $15 \%$ modified particles (Sample 2) followed by the mixture containing $75 \%$ modified powder mixture (Sample 6). This clearly demonstrates that modified powder reduces agglomeration, improves dispersion, and strong interactions 
Maria SÖNMEZ, Laurenţia ALEXANDRESCU, Mihai GEORGESCU, Dana GURĂU, Ciprian CHELARU, Mircea JUGĂNARU, Anton FICAI,

\section{Roxana TRUŞCĂ}

occur between the phases in the system, even at high amounts of reinforcing agents. Elasticity also improves for mixtures containing 15 or $45 \%$ modified powders, but decreases to high volumes (Sample 6), and for mixtures containing unmodified powders. In most cases, elasticity and elongation at break decrease with the increase in the amount of powders, due to reduced mobility of the macromolecular chains. Instead, higher values of the $100 \%$ modulus were obtained mainly for high hardness mixtures, respectively, when modified particles were used. The flow properties of composite mixtures improve if a mixture of unfunctionalized/functionalized particles is used up to a percentage of $(15 \%$ and $45 \%$ ), respectively, of the reference sample (SBS). In contrast, for composites containing high amounts of particles $75 \%$, the flow properties drop to $244-132 \mathrm{~g} / 10 \mathrm{~min}$. However, during the process of obtaining the composites, there were no problems of processability.

Table 3: Physico-mechanical and rheological characteristics for obtained composite materials

\begin{tabular}{lccccccc}
\hline Sample / Characteristic & SBS & 1 & 2 & 3 & 4 & 5 & 6 \\
\hline \multicolumn{7}{c}{ PHYSICO-MECHANICAL } \\
\hline Hardness, ${ }^{0}$ ShA & 60 & 59 & 60 & 66 & 71 & 73 & 78 \\
Tensile strength, N/mm ${ }^{2}$ & 1.29 & 3.17 & 3.83 & 3.08 & 3.28 & 3.15 & 3.65 \\
Module 100\% & 1.18 & 1.19 & 1.56 & 1.55 & 2.2 & 2.37 & 3.13 \\
Module 300\% & - & 2.99 & 3.53 & - & 3.10 & - & - \\
Elongation at break, \% & 120 & 300 & 400 & 260 & 320 & 280 & 160 \\
Elasticity, \% & 34 & 37 & 38 & 40 & 42 & 37 & 34 \\
Tear resistance, N/mm & 8.97 & 15. & 20.27 & 20.05 & 21.99 & 20.97 & 19.07 \\
& \multicolumn{7}{c}{ RHEOLOGICAL - Melt Flow Index } \\
\hline MFI, g/10 min & 278 & 328 & 311 & 309 & 295 & 242 & 132 \\
\hline
\end{tabular}

\section{CONCLUSIONS}

The affinity of powder surface to the modification with $\mathrm{TiO}_{2}$ and $\mathrm{SiO}_{2}$ precursors depends on the presence of reactive groups on the surface as well as on the type of powder used. Although kaolin has a much higher number of reactive groups than magnesium and calcium carbonate, the percentage of $\mathrm{TiO}_{2}$ remaining on the surface of magnesium carbonate is the highest, basedon resultsfrom theEDSquantitative analysis. The presence of $\mathrm{TiO}_{2}$ and/or $\mathrm{SiO}_{2}$ on the surface of powders leads to a reduction in agglomerations due to reduced electrostatic attraction forces. The use of modified powders in the SBS matrix improves physico-mechanical properties due to a reduction in agglomerations/ voids and to the formation of strong interactions at the interface. Hardness and melt flow index are reduced in the case of composites containing modified powders, however, they stay within acceptable limits for obtaining finished products by extrusion-injection.

\section{Acknowledgements}

This work was supported by a grant of the Romanian Ministry of Research and Innovation, CCCDI - UEFISCDI, project number PN-III-P22.1-Cl-2018-1056 - Thermoplastic polymer and nano/micro particle-based fireproof protection sole for firefighters, ctr. No. $183 \mathrm{Cl} / 2018$, within PNCDI III.

\section{REFERENCES}

1. Djetoui, Z., Djerbou, F., Pereña, J.M., Benavente, R., The rheological behavior of wheat starch particulates filled uncured styrene-butadiene rubber, Iran I Chem Chem Eng, 2017, 36, 1, 159-172.

2. Lin, Y., Liu, S., Peng, J., Liu, L., The filler-rubber interface and reinforcement in styrene butadiene rubber composites with graphene/ silica hybrids: A quantitative correlation with the constrained region, Compos Part $A$, 2016, 86, 19-30, https://doi.org/10.1016/j. compositesa.2016.03.029.

3. Fan, Y. et al., Comparative study on carboxylated styrene butadiene rubber 
composites reinforced by hybrid fillers of rice bran carbon and graphite carbon, Carbon Lett, 2018, 27, 72, https://doi.org/10.5714/ CL.2018.27.072.

4. Ahmed, J.K., Al-maamori, M.H., Ali, H.M., Effect of nano silica on the mechanical properties of styrene-butadiene rubber (SBR) composite, International Journal of Materials Science and Applications, 2015, 4, 2-1, 15-20, https://doi.org/10.11648/j. ijmsa.s.2015040201.14.

5. Vuluga, Z., Paceagiu, J., lorga, M., Moanță, A., Pop, H., Thermal and mechanical properties of polypropylene/siliceous filler/styrene butadiene styrene composites, Rev Rom Mater, 2017, 47, 2, 230 -236.

6. Salman, A.A., Improvement the mechanical properties of styrene butadiene rubber by using silica fume, European Journal of Engineering Research and Science, 2017, 2, 12, 31-33, https://doi.org/10.24018/ ejers.2017.2.12.568.

7. Saba, N., Tahir, P.M., Jawaid, M., A review on potentiality of nano filler/natural fiber filled polymer hybrid composites, Polymers, 2014, 6, 8, 2247-2273, https://doi.org/10.3390/ polym6082247.

8. Ozdemir, N.G., Zhang, T., Aspin, I., Scarpa, F., Hadavinia, H., Song, Y., Toughening of carbon fibre reinforced polymer composites with rubber nanoparticles for advanced industrial applications. Express Polym Lett, 2016, 10, 5, 394-407, https://doi.org/10.3144/ expresspolymlett.2016.37.

9. Borba, P.M., Tedesco, A., Lenz, D.M., Effect of reinforcement nanoparticles addition on mechanical properties of SBS/curauá fiber composites, Mat Res, 2014, 17, 2, 412-419, https://doi.org/10.1590/S151614392013005000203.

10. Costa, P., Silva, J., Sencadas, V., Mechanical, electrical and electro-mechanical properties of thermoplastic elastomer styrenebutadiene-styrene/multiwall carbon nanotubes composites, J Mater Sci, 2013, 48, 3, 1172-1179, https://doi.org/10.1007/ s10853-012-6855-7.

11.Fan, Y., Fowler, G.D., The potential of pyrolytic biomass as a sustainable biofiller for styrene-butadiene rubber, Advanced Surface Engineering Research, 2018, IntechOpen,
89-104, https://doi.org/10.5772/ intechopen.79994.

12.Perov, N.S., Relaxation properties of thermoplastic styrene-butadiene block copolymer with nanodiamond filler, Inorganic Materials: Applied Research, 2018, 9, 4, 670-674, https://doi.org/10.1134/ S2075113318040275.

13.Zulkafal, H.M., Asif, M., Yasin, T., Kanwal, S., Khan, M.A., Study of thermal oxidative ageing and gamma irradiation effects on styrene butadiene rubber/boron carbide based composites, Journal of Chemical Engineering \& Process Technology, 2018, 9, 2, 1-6.

14.Song, X., Yoshino, H., Shibata, H., Nagatani, A., Ueda, Y., Mechanical Properties of Styrene-Butadiene-Styrene Block Copolymer Composites Filled with Calcium Carbonate Treated by Liquid Polybutadienes, J Appl Polym Sci, 2009, 113, 6, 3661-3670, https:// doi.org/10.1002/app.30362.

15.Cao, Z., Daly, M., Lopez, C., Geever, L.M., Major, I., Higginbotham, C.L., Devine, D.M., Chemical surface modification of calcium carbonate particles with stearic acid using different treating methods, App/SurfSci, 2016, 378, 320-329, https://doi.org/10.1016/j. apsusc.2016.03.205.

16. Wypych, G., Handbook of Fillers, 4th Edition, 2016, ChemTec Publishing.

17. Pedrosa, J. et al., Surface properties of calcium carbonate modified with silica by sol-gel method, Colloids Surf A Physicochem Eng Asp, 2016, 497, 1-7, https://doi.org/10.1016/j. colsurfa.2016.02.020.

18.Tsutsumi, R., Sasaki, T., Hashiguchi, C., Yamazaki, R., Fujii, S., Nakamura, Y., Hikasa, S., Surface treatment of $\mathrm{CaCO}_{3}$ with a mixture of amino- and mercapto-functional silane coupling agents and tensile properties of the rubber composites, Compos Interface, 2018, 25, 8, 743-760, https://doi.org/10.1080/0927 6440.2018 .1439629 .

19.Zhang, J., Guo, J., Li, T., \& Li, X., Chemical surface modification of calcium carbonate particles by maleic anhydride grafting polyethylene wax, Int I Green Nanotechnol Phys Chem, 2010, 1, 2, 65-71, https://doi. org/10.1080/19430871003684341.

20.Zhang, X.Q., Wu, W., Zeng, X.F., Chen, J.F.,

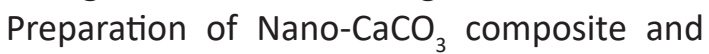


Maria SÖNMEZ, Laurenţia ALEXANDRESCU, Mihai GEORGESCU, Dana GURĂU, Ciprian CHELARU, Mircea JUGĂNARU, Anton FICAI,

Roxana TRUŞCĂ

mechanical properties of nano- $\mathrm{CaCO}_{3}-\mathrm{PVC}$ composite, J Mater Sci Technol, 2007.

21.Shao, G.N. et al., Sol-gel synthesis of photoactive kaolinite-titania: Effect of the preparation method and their photocatalytic properties, Appl Surf Sci, 2015, 331, 98-107, https://doi.org/10.1016/j. apsusc.2014.12.199.

22.Bharadwaj, P., Singh, P., Pandey, K.N., Verma, V., Srivastava, S.K., Structure and Properties of Styrene-butadiene Rubber/Modifed Hectorite Clay Nanocomposites, Applied Polymer Composites, 2013, 1, 4, 207-224.

23.Zhang, Y., Song, H., Liu, Q., Zhang, S., Zhang, $Y$., Dynamic mechanical property of kaolinite/ styrene-butadiene rubber composites, Mater Sci Eng CMater Biol Appl, 2017, 8, 2412-5954.

24.Lu, Y., Jiang, N., Li, X., Shiai, X., Effect of inorganic-organic surface modification of calcium sulfate whiskers on mechanical and thermal properties of calcium sulfate whisker/poly(vinyl chloride) composites, RSC Adv, 2017, 7, 46486-46498, https://doi. org/10.1039/C7RA09193A.

25.Lan, S., Zhu, D., Li, L., Liu, Z., Zeng, Z., Song, F., Surface modification of magnesium hydroxide particles using silane coupling agent by dry process, Surf Interface Anal, 2017, 50, 3, 277283, https://doi.org/10.1002/sia.6363.

26.Zhang, H., Wang, H., Wang, H., Flame retardant mechanism and surface modification of magnesium hydroxide flame retardant, IOP Conference Series Earth and Environmental Science, 2018, 170, 3, 1-6, https://doi. org/10.1088/1755-1315/170/3/032028.

27.Barbosa, L.V. et al., Kaolinite-titanium oxide nanocomposites prepared via solgel as heterogeneous photocatalysts for dyes degradation, Catal Today, 2015, 246, 133-142, https://doi.org/10.1016/j. cattod.2014.09.019.

28.Aroke, O.U., Abdulkarim, A., Ogubunka, O.R., Fourier-transform infrared characterization of kaolin, granite, bentonite and barite, Journal of Environmental Technology, 2013, 6, 1, 4253.

29.Tironi, A., Trezza, M.A., Irassar, E.F., Scian, A.N, Thermal treatment of kaolin: Effect on the pozzolanic activity, Procedia Mater Sci, 2012, 1, 343-350, https://doi.org/10.1016/j. mspro.2012.06.046.
30.Saikia, B.J., Parthasarathy, G., Fourier Transform Infrared Spectroscopic Characterization of Kaolinite from Assam and Meghalaya, Northeastern India, Journal of Modern Physics, 2010, 1, 4, 206-210, https:// doi.org/10.4236/jmp.2010.14031.

31.Galván-Ruiz, M., Hernández, J., Baños, L., Rodriguez-Garcia, M.E., Characterization of Calcium Carbonate, Calcium Oxide, and Calcium Hydroxide as Starting Point to the Improvement of Lime for Their Use in Construction, J Mater Civil Eng, 2009, 21, 11, 625-708, https://doi.org/10.1061/ (ASCE)0899-1561(2009)21:11(694).

32.Kiros, A., Gholap, A.V., Gigante, G., Fourier transform infrared spectroscopic characterization of clay minerals from rocks of Lalibela churches, Ethiopia, Int J Phys Sci, 2013, 8, 109-119.

33.Munteanu, S.B., Vasile, C., Spectral and thermal characterization of styrenebutadiene copolymers with different architectures, J Optoelectron Adv M, 2005, 7, 6, 3135-3148.

34.Navarro-Bañón, M.V., Pastor-Blas, M.M., Martín-Martínez, J.M., Environmental friendly surface treatment of SBS rubber with acidified chloramine $T$ aqueous solutions, Rubber Chem Technol, 2007, 80, 1, 139-158, https://doi.org/10.5254/1.3548161.

35.Shimpi, N., Mali, A., Hansora, D.P., Mishra, S., Synthesis and surface modification of calcium carbonate nanoparticles using ultrasound cavitation technique, Nanoscience and Nanoengineering, 2015, 3, 1, 8-12.

(C) 2019 by the author(s). Published by INCDTPICPI, Bucharest, RO. This is an open access article distributed under the terms and conditions of the Creative Commons Attribution license (http:// creativecommons.org/licenses/by/4.0/). 